\title{
Program Peningkatan Kemandirian Ekonomi Panti Asuhan Syifa'ul Qolbi
}

\author{
Risgiyanti $^{1)}$, Ana Shohibul ${ }^{2)}$
}

\author{
Jurusan Manajemen, Fakultas Ekonomi dan Bisnis, Universitas Sebelas Maret, Indonesia ${ }^{1)}$ \\ Jurusan Ekonomi Pembangunan, Fakultas Ekonomi dan Bisnis, Universitas Sebelas Maret, \\ Indonesia $^{2)}$ \\ Pos-el: risgiyanti@staff.uns.ac.id ${ }^{1)}$; shohibulana@staff.uns.ac.id ${ }^{2)}$
}

\begin{abstract}
Abstrak
Panti Asuhan Syifa'ul Qolbi memiliki fasilitas penunjang berupa konveksi kecil sebagai wadah untuk pelatihan keterampilan menjahit bagi anak asuh disamping sebagai tempat usaha. Namun perkembangan usaha ini mengalami beberapa kendala seperti manajemen bisnis yang masih tradisional, strategi pemasaran yang belum optimal, peralatan produksi yang belum efisien serta kurangnya motivasi dan jiwa kewirausahaan anak asuh. Program pengabdian masyarakat ini bertujuan untuk mengembangkan usaha panti asuhan di bidang fashion dan menumbuhkan karakter kewirausahaan anak-anak asuh supaya mereka dapat memanfaatkan potensinya secara lebih baik di masa yang akan datang.

Beberapa programworkshop kewirausahaan, pelatihan desain dan pola, pelatihan manajemen bisnis, pelatihan e-marketing, pembuatan merek produk dan konsep pemasaran serta pendampingan usaha telah dilaksanakan dengan baik. Hasil dari program pengabdian kepada masyarakat ini adalah peningkatan motivasi dan karakter kewirausahaan peserta pelatihan, peningkatan keterampilan desain dan pola jahit, peningkatan pengetahuan manajemen bisnis, terciptanya merek, sarana pemasaran online serta dan peningkatan kualitas produksi. Progam ini juga memberikan bantuan peralatan penunjang produksi untuk peningkatan efisiensi dan efektifitas.
\end{abstract}

Kata Kunci: industri fashion, kewirausahaan, motivasi

\section{Abstract}

Syifa'ul Qolbi Orphanage holds supporting facility in the form of confection. In addition to a business, this confection functions as a place to train the orphans' sewing skill. Yet the development of this business faces a number of obstacles such as traditional business management, sub-optimal marketing strategy, inefficient production tools and the training participants' lack of motivation and entrepreneurship. This community service attempted to realize the orphanage management's goal of developing their fashion business and developing entrepreneurship among the orphans so that they can optimize their potential in the future.

Some of the programs have been held through community service.The programs were entrepreneurship workshop, pattern and design training, business management training, $e$ marketing training, branding and marketing concept, and business accompaniment. This community service results in the improvement of participant's motivation and entrepreneurship character,bussiness management knowledge,and skill in making pattern and design. The other results are fashion brand creation, digital marketing facility, and quality product improvement.This program also give several production equipments to help the improvement of eficiency and effectivity. 
Keywords: entrepreneurship, motivation, fashion

\section{PENDAHULUAN}

Saat ini, para generasi muda harus siap menghadapi berbagai tantangan perubahan dalam segala bidang kehidupan seiring pesatnya perkembangan teknologi dan arus globalisasi. Mencetak generasi muda yang unggul butuh komitmen bersama yang kuat antar elemen masyarakat dan pemerintah. Fakta yang cukup ironis saat ini dihadapan kita adalah semakin banyak generasi muda yang rusak moralnya akibat gagal dalam berasimilasi dengan perubahan lingkungan sosial dan budaya. Tak sedikit dari mereka terjerumus dalam pergaulan bebas dan konsumsi obat terlarang serta menggadaikan pendidikan mereka pada aktivitas yang tidak bermanfaat. Padahal kita ketahui bersama bahwa generasi muda adalah generasi penerus bangsa yang akan menentukan maju tidaknya suatu bangsa di masa yang akan datang(Kansil, 2006).

Anak yatim piatu, anak yatim, maupun piatu termasuk generasi penerus bangsa yang sama-sama memiliki cita-cita untuk turut serta membangun bangsa. Mereka adalah anakanak yang belum dewasa dan sudah tidak memiliki orang tua (anak yatim piatu) atau tidak memiliki ayah (anak yatim) atau tidak memiliki ibu (piatu) sebagai penanggung jawab dalam hidupnya(Shihab, 1997:507). Mereka juga biasanya lemah secara ekonomi dan tidak mendapatkan akses sosial secara optimal seperti pendidikan, kesehatan, perlindungan terhadap kekerasan serta seringkali terabaikan haknya. Bahkan tidak sedikit dari mereka yang memiliki masa depan suram karena tumbuh menjadi anak yang kurang perhatian dan perlindungan. Padahal mereka memiliki potensi menjadi generasi yang unggul ketika mereka dipelihara dan diasuh dengan baik. Mereka membutuhkan perlindungan secara penuh baik dari pemerintah maupun seluruh lapisan masyarakat untuk menjalankan kehidupan dan hakhak mereka agar masa depan mereka lebih baik

Dengan demikian pembinaan anak yatim piatu, anak yatim maupun anak piatu yang lemah menjadi kewajiban kita bersama. Jangan sampai mereka terjerumus ke dalam dunia yang dapat mengancam masa depan mereka. Inilah yang menjadi alasan Yayasan Syifa' Al Qolbi mendirikan sebuah panti asuhan untuk mengakomodasi kebutuhan para anak-anak yang masuk golongan yatim piatu, yatim, piatu maupun anak kurang mampu. Panti asuhan tersebut mereka namai Panti Asuhan Syifa'ul Qolbi. Panti asuhan ini terletak di daerah yang cukup jauh dari hiruk pikuk perkotaan dengan lingkungan yang cukup asri. Di panti asuhan ini ada anak yang menetap dan tinggal di panti serta ada pula yang tidak menetap. Panti ini memiliki cita-cita menjadikan anak-anak asuh mereka menjadi insan yang mulia yang unggul dalam ilmu agama maupun pengetahuan serta memiliki keterampilan agar mampu bermanfaat bagi dirinya dan masyarakat sekitar. Panti ini membekali anak-anak asuh dengan pendidikan ilmu agama serta akses ke pendidikan formal. Selama ini pembiayaan panti ini megandalkan dari bantuan para donatur dan uniknya panti ini memiliki usaha sampingan berupa konveksi dan menfasilitasi anak-anak asuh mereka yang sudah mulai remaja dengan keterampilan menjahit. Usaha ini mendapat respon yang sangat baik dari masyarakat sekitar dengan mulai banyaknya pesanan. Namun karena keterbatasan ilmu dan keterampilan serta sarana yang 
dimiliki usaha ini belum mampu memberikan nilai tambah ekonomi secara optimal. Selain itu, ada keinginan dari para pengurus panti untuk mengembangkan usaha mereka supaya tidak sekedar menerima pesanan jait namun juga mampu memproduksi produk fashion yang marketable. Cita-cita ini masih terhambat karena terbatasnya pengetahuan seputar teknik menjahit profesional terutama terkait desain dan pola. Mereka memiliki keinginan menghasilkan produk fashion seperti gamis, mukena, koko, kerudung, dan lainnya yang mereka beli label sendiri dan dapat dipasarkan secara luas.

Disamping itu,potensi anak-anak asuh yang mengikuti pelatihan menjahit juga belum tergali secara maksimal dan menghasilkan output yang diharapkan. Banyak dari mereka setelah terampil enggan memanfaatkan keterampilannya untuk menopang hidupnya setelah tidak lagi menjadi anak asuh. Kurangnya minat dan jiwa kewirausahaan yang belum dimiliki membuat mereka enggan memanfaatkan keterampilannya. Padahal, saat ini peluang di industri fashion sangat menjanjikan seiring kemajuan teknologi dan informasi. Banyak anakanak muda yang berhasil menjadi produsen fashion berbasis online marketing dengan penghasilan besar bermula dari usaha kecil-kecilan. Hal inilah yang melatarbelakangi kegiatan Pengabdian Kepada Masyarakat (PKM) yang bertujuan untuk meningkatkan kemandirian ekonomi Panti Asuhan Syifaul Qolbi. Kegiatan ini merupakan program pemberdayaan untuk membangun potensi, memberikan motivasi, serta membangkitkan kesadaran akan potensi yang dimiliki serta berupaya untuk mengembangnya. Hal ini karenan setiap manusia dan masyarakat khususnya di lingkungan panti asuhan memiliki potensi yang dapat dikembangkan (Moleijarto, 1996).

Adapun metode yang akan diterapkan untuk membantu meningkatkan kemandirian panti secara ekonomi diantaranya melalui pelatihan kewirausahaan, pelatihan desain dan pola, pelatihan manajemen bisnis, pelatihan e-marketing, pembuatan branding produk, pembuatan konsep pemasaran serta pendampingan. Langkah ini diharapkan akan mampu meningkatkan efektifitas panti asuhan beserta anak asuhnya dan membantu pemerintah mewujudkan program pengembangan ekonomi masyarakat di bidang kewirausahaan.

\section{METODE PELAKSANAAN}

Program pengabdian masyarakat ini mencoba untuk mewujudkan cita-cita pengelola suatu panti asuhan untuk mengembangkanusaha mereka di bidang fashion dan menumbuhkan karakter kewirausahaan anak-anak asuh supaya mereka dapat memanfaatkan potensinya secara lebih baik di masa yang akan datang.Panti Asuhan Syifa'ul Qolbi merupakan panti asuhan yang didirikan oleh Yayasan Syifa' Al Qolbi. Panti ini terletak di Dukuh Ngasinan, Desa Tugu, Kecamatan Jumantono, Kabupaten Karanganyar, Provinsi Jawa Tengah. Panti ini dikelola oleh Bapak Rahmat Sugiyono. Panti Asuhan Syifa'ul Qolbi memiliki fasilitas penunjang berupa konveksi kecil sebagai wadah untuk pelatihan keterampilan menjahit bagi anak asuh disamping sebagai tempat usaha.

Program pengabdian kepada masyarakat ini dilaksanakan dengan durasi waktu 3 bulan. Adapun metode pelaksanaan pengabdian masyarakat ini menggunakan kaji tindak. Pertamatama tim melakukan identifikasi untuk menemukan masalah maupun peluang. Kemudian tim menyusun rencana kegiatan untuk memecahkan solusi dan menangkap peluang dari hasil 
identifikasi, pelaksanaan rencana kegiatan, dan evaluasi. Adapun rencana kegiatan yang disusun adalah sebagai berikut:

a. Pelatihan kewirausahaan

Pelatihan ini diharapkan dapat mengubah pola pikir para peserta pelatihan dari "pencari kerja" menjadi "pencipta kerja" serta para peserta pelatihan nanti mampu menginternalisasikan karakter entrepreneurship dan meningkatkan motivasi berwirausaha(Kasali, 2010).

b. Pelatihan desain dan pola

Pelatihan ini diharapkan mampu meningkatkan keterampilan teknis peserta pelatihandi bidang produksi pakaian.

c. Pelatihan manajemen bisnis

Pelatihan ini diharapkan mampu meningkatkan keterampilan mengelola bisnis secara efektif dan efisien

d. Pelatihan e-marketing

Pelatihan ini diharapkan mampu meningkatkan keterampilan peserta pelatihan di bidang pemasaran digital

e. Pembuatan merek produk dan konsep pemasaran

Kegiatan bertujuan untuk menciptakan merek usaha dan merumuskan metode pemasaran efektif

f. Pendampingan

Kegiatan pelatihan saja tidak cukup untuk mencapai tujuan PKM. Pendampingan merupakan upaya untuk terus memantau hasil dari efektifitas suatu pelatihan pada tahap implementasi.

\section{HASIL DAN PEMBAHASAN}

Berdasarkan metode pelaksanaan yang dirumuskan sebelumnya, kegiatan pengabdian masyarakat ini dimulai dengan pelatihan kewirausahaan. Kurangnya motivasi kewirausahaan di lingkungan anak asuh terutama mereka yang telah mendapat pelatihan menjahit dari pihak panti merupakan hal yang melatarbelakangi kegiatan pelatihan kewirausahaan. Peserta pelatihan ini berjumlah 15 orang yang terdiri dari para anak asuh panti asuhan dan beberapa masyarakat sekitar yang berprofesi sebagai buruh jahit. Di dalam pelatihan ini, para peserta pelatihan diubah pola pikirnya mengenai konsep kewirausahaan. Mereka diajak melihat fakta kesuksesan para pengusaha sukses yang memiliki kisah inspiratif, mengenal karakter wirausaha, dan belajar cara memulai usaha baru. Banyak peserta yang mengaku tergugah jiwa wirausahanya dan termotivasi untuk mengikuti jejak para pengusaha sukses yang memulai usahanya dari nol.

Program PKM dilanjutkan dengan pelatihan pembuatan desain dan pola. Pelatihan ini bekerjasama dengan praktisi dari tim Primadona Textile dan Taylor Surakarta. Pelatihan ini berlangsung selama empat kali pertemuan.Dengan peserta pelatihan yang sama, pelatihan ini mampu meningkatkan keterampilan peserta dibidang teknis pembuatan desain dan pola karena mereka dilatih langsung oleh praktisi. Di dalam pelatihan ini, peserta belajar teknik dasar pembuatan desain pakaian yang sedang diminati masyarakat saat ini dan mewujudkannya dalam suatu pola. Dari pola yang berhasil dibuat, para peserta secara 
berkelompok menjahitnya sampai tercipta pakaian jadi hasil dari pelatihan. Dalam pelatian ini, praktisi juga memberikan materi dan tips berkaitan bisnis jasa menjahit yang memiliki peluang sangat menjanjikan saat ini. Kegiatan ini meningkatkan keterampilan peserta dalam pembuatan desain dan pola serta teknik dalam menjahiy pakaian yang baik dan tepat.

Setelah pelatihan pembuatan desain dan pola, program PKM dilanjutkan dengan pelatihan manajemen bisnis. Kita megetahui bersama bahwa masalah klasik dari Usaha mikro, kecil dan menengah (UMKM) saat ini adalah kurangnya literasi manajemen bisnis yang efektif. Mereka umumnya belum mampu mengelola usahanya secara efektif dan efisien. Pelatihan ini memberikan pengetahuan wawasan kepada peserta pelatihan dan pengelola panti asuhan terkait empat fungsi pengelolaan bisnis yang meliputi operasional, pemasaran, sumber daya manusia, dan keuangan. Pelatihan ini memberikan pengetahuan bagi para peserta konsep pengelolaan bisnis yang efektif dan efisien supaya bisnis dapat berkembang pesat ke depannya.

Selain membekali peserta pelatihan dengan manajemen bisnis yang efektif dan efisien, program PKM juga memberikan pelatihan e-marketing atau pemasaran digital mengingat saat ini lingkungan bisnis dituntut untuk memanfaatkan teknologi agar mampu bersaing. Pelatihan ini mengenalkan peserta pelatihan mengenai lingkungan pemasaran digital dan aplikasi apa saja yang bisa dimanfaatkan untuk mendukung pengembangan bisnis terutama dalam hal memasarkan produk mereka. Dari hasil pelatihan ini peserta mengenal aplikasi seperti shoope, instagram, social media post maker, dan InShot yang merupakan aplikasi yang dapat mendukung pemasaran produk.

Setelah memberikan beberapa pelatihan, tim PKM mulai fokus pada bisnis yang dijalankan di panti asuhan yaitu pembuatan merek dan konsep pemasaran. Tim mulai berdiskusi dengan mitra yaitu pihak pengelola panti asuhan khususnya yang mengelola bisnis konveksi pakaian yaitu ibu Sri Mujiyanti untuk mulai membuat merek dagang bisnisnya. Syifa'ul Qolbi yang merupakan nama panti asuhan tersebut menjadi nama merek dagang usaha pakaian tersebut. Setelah nama merek dagang disepakati, tim menfansilitasi untuk pembuatan desain logo yang menarik supaya marketable untuk desain label nama, hangtag, dan plastik kemas pakaian. Kemudian, tim PKM bersama-sama merumuskan konsep pemasaran dimana lagkah awalnya adalah pembuatan akun instagram sebagai sarana mempromosikan produk dan penjualan online. Nama akun instagram yang dibuat adalah syifaulqolbi_atelier. Pemakaian nama tersebut memberi kesan profesional pada nama toko online yang ada pada instagram. Dengan desain yang cantik dan memiliki ciri khas tersendiri dalam setiap postingan, hal ini diharapkan membangun persepsi positif dari konsumen akan merek produk usaha dari panti asuhan.

Selain hal diatas, program PKM ini juga memberikan bantuan alat produksi dalam rangka peningkatan efektifitas dan efisiensi yaitu mesin itik atau mesin jahit portable, mesin obras empat benang, dan mesin jahit industrial yang berjumlah masing-masing satu unit. Pihak panti membutuhkan mesin itik atau mesin jahit portable untuk menghasilkan pakaian yang memiliki desain tertentu yang tidak dapat dilakukan dengan mesin jahit biasa. Selain itu tim PKM juga memberikan bantuan mesin obras empat benang dan mesin jahit industrial untuk membantu pengembangan usaha. Hal ini dikarenakan pihak panti akan memproduksi 
pakaian berbahan kaos sehingga membutuhkan mesin tersebut untuk mendukung kelancaran dan efisiensi proses produksi.

Dalam program PKM ini tim akan melakukan pendampingan secara berkala untuk memantau kelancaran bisnis panti asuhan supaya tujuan peningkatan kemandirian ekonomi panti dapat tercapai. Pendampingan ini juga bertujuan agar apa yang diberikan sebagai materi pelatihan dapat diimplementasikan dengan baik. Berikut adalah beberapa foto kegiatan PKM:
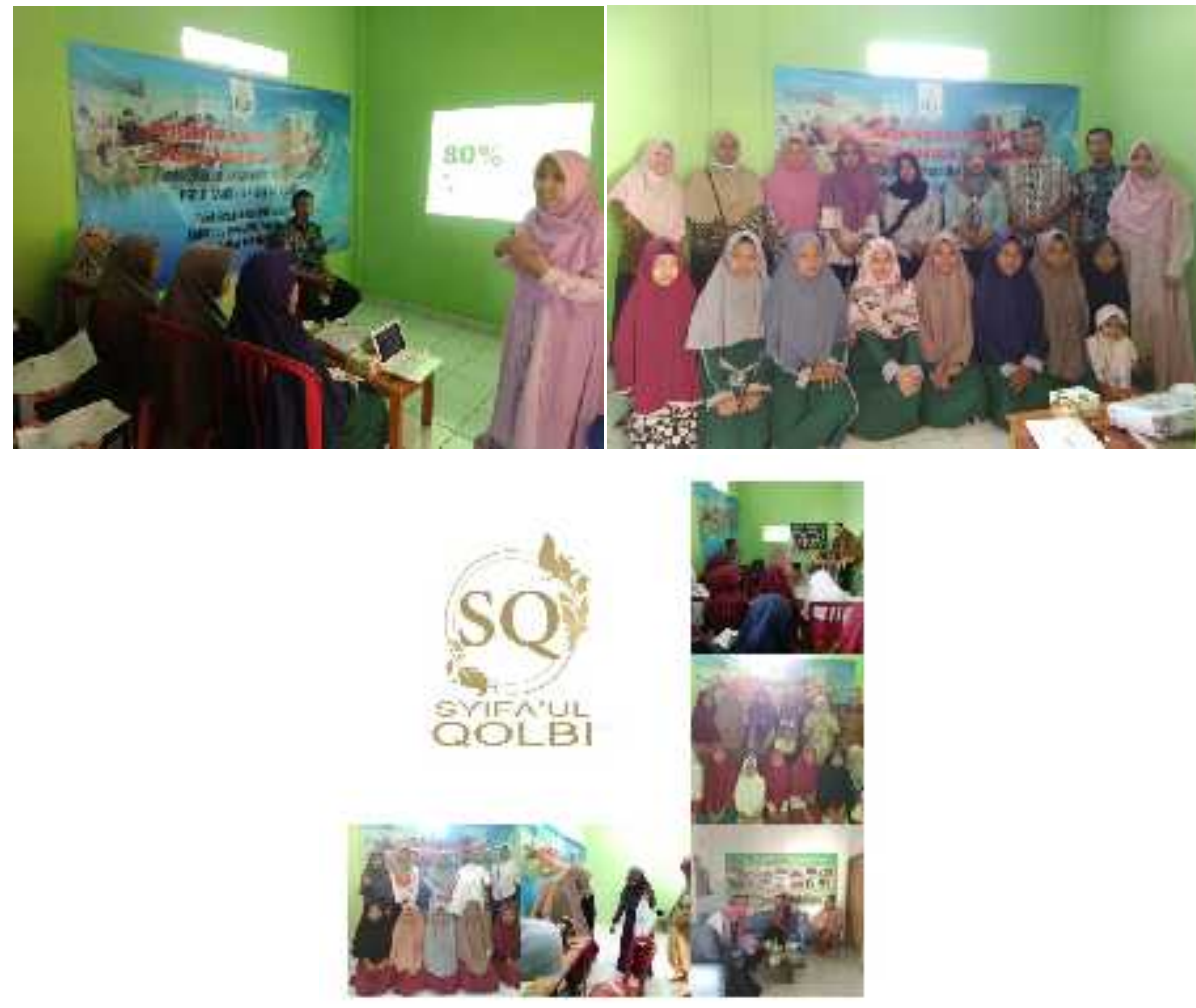

Gambar 1. Dokumentasi pelaksanaan kegiatan program pengabdian 


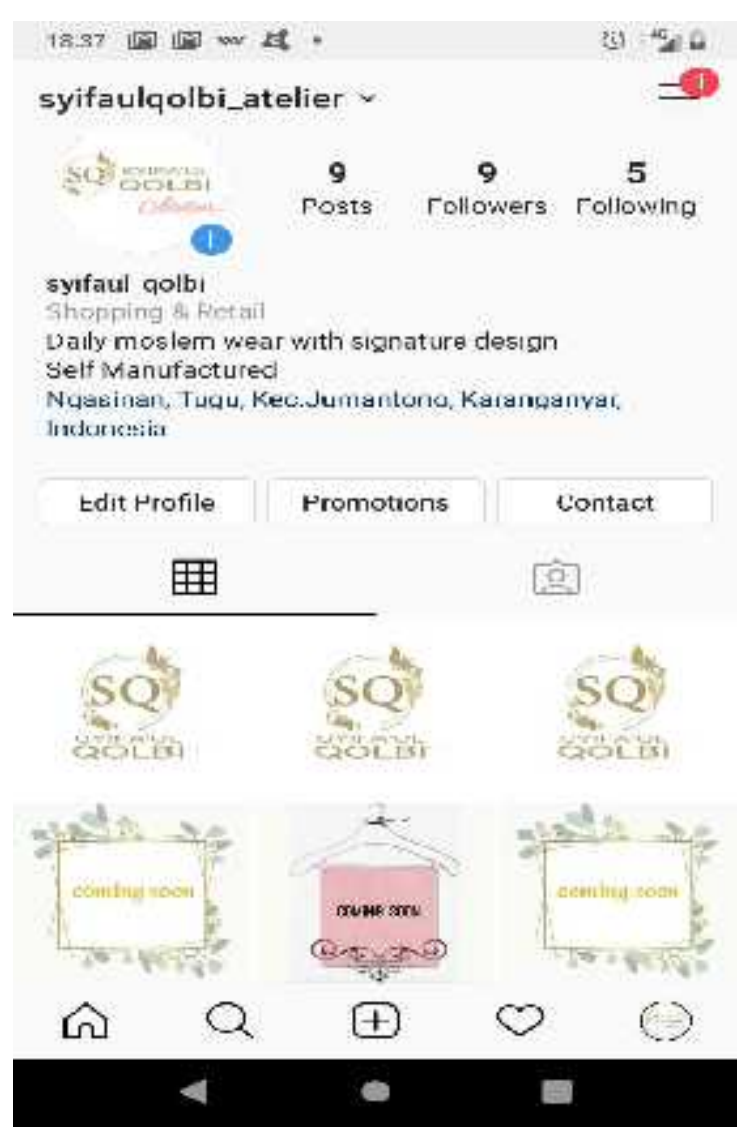

Gambar 2. Akun instagram yang berhasil dibuat

\section{SIMPULAN}

Program pengabdian ini bertujuan untuk meningkatkan kemandirian ekonomi panti asuhan Syifa'ul Qolbi. Ada beberapa program yang dilakukan untuk mencapai tujuan tersebut yaitu pelatihan kewirausahaan, pelatihan pembuatan desain dan pola, pelatihan manajemen bisnis, pelatihan e-marketing, pembuatan merek dan konsep pemasaran serta pendampingan. Program PKM ini juga memberikan bantuan alat produksi dalam rangka peningkatan efektifitas dan efisiensi yaitu mesin itik atau mesin jahit portable, mesin obras empat benang, dan mesin jahit industrial yang berjumlah masing-masing satu unit. Dalam program ini peserta pelatihan berhasil dirubah pola pikirnya untuk tidak sekedar menjadi pencari kerja namun sebagai pencipta kerja melaui konsep kewirausahaan. Peserta pelatihan juga diberikan keterampilan dalam mendesain dan membuat pola yang sesuai permintaan pasar, pengetahuan manajemen bisnis, serta cara memanfaatkan teknologi untuk pemasaran digital. Selain itu, melalui program ini pihak panti asuhan juga telah memiliki label merek dagang dan akun instagram untuk membantu pengembangan usaha mereka serta sudah memiliki konsep pengemasan produk yang marketable.

\section{DAFTAR RUJUKAN}

Kansil, C. S. . (2006). Aku Pemuda Indonesia. Jakarta: Balai Pustaka.

Kasali, R. (2010). Wirausaha Muda Mandiri. Kisah Inspiratif Anak Muda Mengalahkan Rasa Takut dan Bersahabat dengan Ketidakpastian. Menjadi Wirausaha Tangguh. Jakarta: PT.Gramedia 
Pustaka Utama.

Moleijarto. (1996). Pemberdayaan Kelompok Miskin Melalui Program IDT. Jakarta: CSIS.

Shihab, Q. (1997). Tafsir Al-Qur'an Al-Karim. Bandung: Pustaka Indah. 